\title{
Comparison of thymic histology with response to thymectomy in myasthenia gravis
}

\author{
J. M. VETTERS ${ }^{1}$ AND J. A. SIMPSON \\ From the Department of Pathology, Western Infirmary and \\ Institute of Neurological Sciences, Southern General Hospital, Glasgow
}

SYNOPSIS Fifty-four thymus glands removed surgically from patients with myasthenia gravis were examined using an accurate morphometric technique and the data compared with the response to thymectomy. There is a tendency for patients with relatively unreactive thymus glands to obtain a better result from thymectomy but this is not statistically significant.

Germinal centres were first reported in the thymus glands of patients with myasthenia gravis by Barton and Branch (1937) and Miller (1940). They made only passing reference to them; at that time it was believed that the characteristic histological features of the myasthenic thymus was 'hyperplasia'. However, Sloan (1943) recognized that germinal centre formation was the characteristic feature of myasthenic thymus glands. Subsequently, the studies of Keynes (1946, 1949) showed that thymectomy caused amelioration of the patients' clinical status. Despite this, only five groups have studied whether there was any correlation between the histological changes in the thymus and the response to thymectomy.

No uniform opinion has emerged from these studies. Castleman and Norris (1949), in a study of 23 cases, failed to find any relationship between the thymic changes and the response to thymectomy. Mackay et al. (1968) studied 10 patients and concluded that the patients who did best were a group of young females whose thymus glands contained numerous germinal centres. Alpert et al. (1971) studied 79 myasthenic patients, assessing the thymic histology semiquantitatively, and noted that the most favourable response to thymectomy was obtained in subjects whose thymus gland contained few or no germinal centres. Seybold et al. (1971) in a study of 102 patients with juvenile myas-

1 Present address: Division of Pathology, The University of Calgary, Calgary, Alberta T2N 1N4, Canada. thenia gravis could detect no correlation between 'thymic hyperplasia' and the response to thymectomy. Finally, Reinglass and Brickel (1973) studied 12 patients and failed to detect any correlation between the histological appearances and the response to thymectomy.

The present study using strict histological quantitation methods was initiated to determine the following:

1. If the percentages of thymus glands occupied by cortex and medulla in subjects with myasthenia gravis differs from the data obtained by Hammar (1926) in a study of normal subjects who died suddenly - that is, do they show stress involution or other changes in the amounts of cortex and medulla present?

2. The relationship between the density of germinal centres and the following: (a) response to thymectomy; (b) age at thymectomy; (c) duration of symptoms preoperatively.

3. Relationship between germinal centre size and the postoperative response.

\section{METHODS}

THYMIC QUANTITATION All available blocks were studied. The area of each section and the percentage of it occupied by cortex, medulla, and interstitial tissue were determined by methods previously described (Vetters and Barclay, 1973).

As previously discussed (Vetters and Barclay, 1973), the human thymus may contain structures which have all the classical features of germinal centres (GC) - that is, lymphocyte cuff, pale centre 
containing reticulum cells macrophages, tingible bodies, and mitotic figures. However, a second structure is frequently present-we have named them 'rounded lymphoid clusters' (RLC). These show a range of appearances. (1) Dense aggregate of lymphocytes with the peripheral lymphocytes arranged concentrically. (2) Lymphocyte cuff with a pale centre; no tingible bodies or macrophages present. (3) Lymphocyte cuff with pale centre; either tingible bodies or mitoses present.

Evidence was produced to show that the RLC are usually obliquely sectioned germinal centres. They are enumerated separately here because some authors-for example, Goldstein and Mackay (1967)

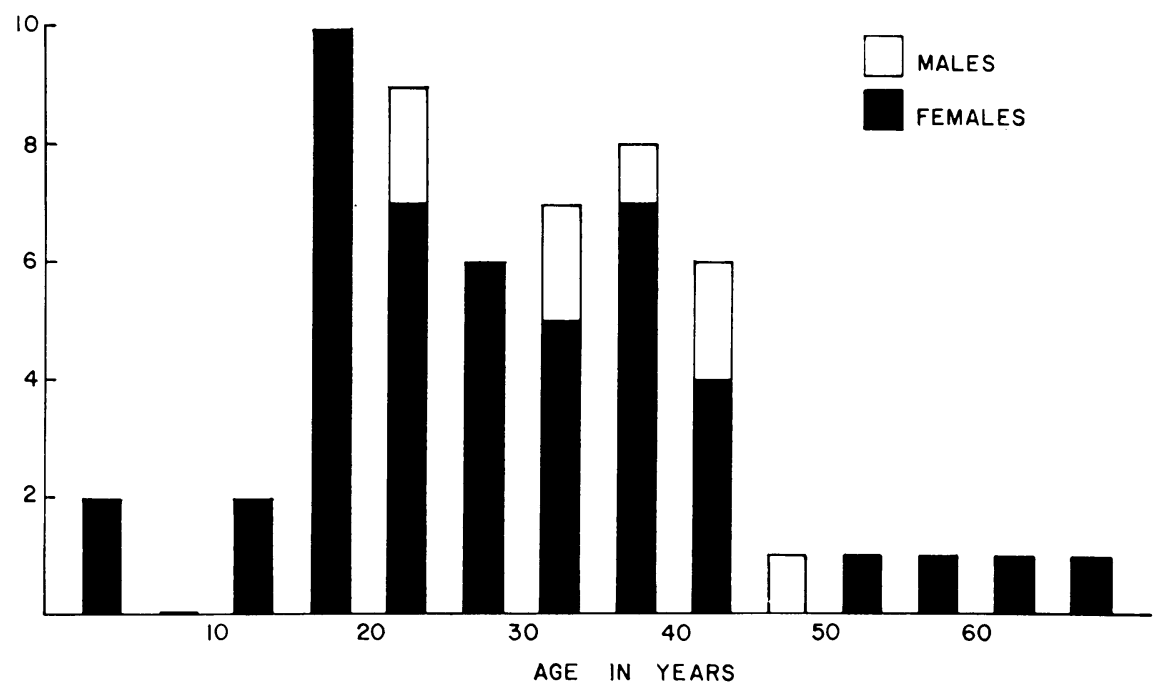

FIG. 1. Age of subjects at thymectomy. Although the patients' ages ranged from 2 years to 66 years at the time of operation, the vast majority of them were between 15 and 45 years of age.

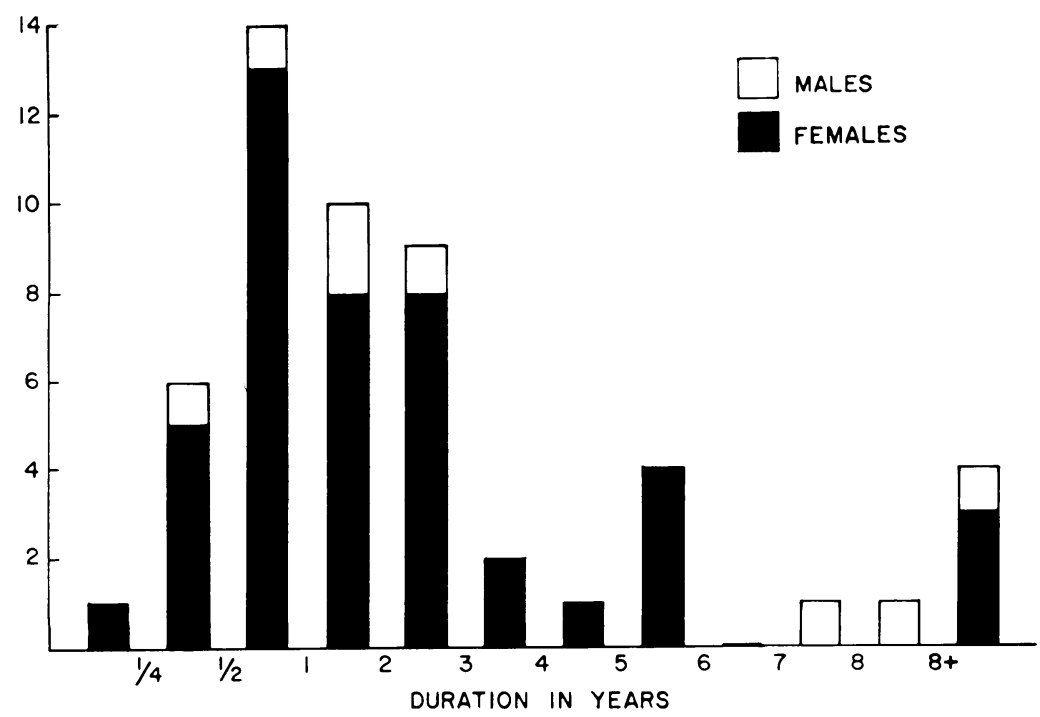

FIG. 2. Duration of symptoms preoperatively. The average duration of symptoms preoperatively was three years. It should be noted that this figure is somewhat misleading and that 31 of the cases were operated on within two years of the onset of symptoms. If the four cases not operated on for eight or more years are excluded, the mean duration of symptoms is approximately I.7 years. 
- disregard structures other than classical germinal centres. The number of germinal centres and RLC in each section was recorded. Their size was determined by measuring each structure in two axes at right angles and calculating the mean.

From the data obtained, it was possible to calculate the percentage of each gland occupied by cortex and medulla, the density of germinal centres $/ \mathrm{cm}^{2}$ medulla and to obtain a ratio of the number of germinal centres to the area of cortex present. These figures were analysed statistically using a HewlettPackard 9100B calculator.

CLINICAL EVALUATION The clinical assessment was made by J.A.S. from his clinical notes using the same grading system as Alpert et al. (1971). The assessment was performed without knowledge of the results of the quantitation studies.

DETAILS OF GROUP STUDIED A total of 54 patients was studied. Of these, six had thymic tumours; their ages were 32, 41, 43, 49, 59, and 65 years. Excluding two subjects with juvenile myasthenia gravis (both 2 year old females), the average age of the remaining subjects was $27 \cdot 8 \pm 10 \cdot 9$ years. The age distribution of the subjects without thymic tumours is shown in Fig. 1.

The duration of symptoms before surgery is shown in Fig. 2. The average duration of symptoms preoperatively was 3.0 years; the standard error of the mean was 3.7 . The rather long preoperative period is largely due to the inclusion of early Glasgow thymectomy cases and patients referred from other centres; both of these groups were given prolonged medical treatment before surgery was undertaken. When circumstances permit, we prefer to operate at an earlier time.

\section{RESULTS}

COMPARISON WITH HAMMAR'S DATA FOR SUBJECTS WHO DIED SUDDENLY It is known from the experimental and clinical studies (de Sousa and Fachet, 1972; Hammar, 1926, 1929) that disease or stress causes rapid involution of the thymus gland. For this reason, Hammar's (1926) data obtained by study of thymus glands removed from previously healthy subjects who died suddenly remains the best information on the variations of cortex and medulla found in normal subjects. The data of groups of thymus glands were compared with Hammar's figures.

Juvenile myasthenia gravis Definitions of juven- ile myasthenia vary. Subjects of 12 years and over have been excluded from this group. Only two subjects had this unusual form. Both were 2 year old females. Neither thymus contained germinal centres. The percentages of thymus occupied by cortex were 52.5 and 59.6 respectively and the percentages occupied by medulla were $18 \cdot 2$ and $25 \cdot 2$. The mean values given by Hammar's data on 28 children ranging up to 5 years old are $56.8 \pm 1.7$ and $21.8 \pm 0.9$ for cortex and medulla respectively. It is therefore clear that these two subjects do not show a consistent alteration from the figures given by Hammar (1926).

Adult myasthenia gravis not associated with thymic neoplasm There were 46 cases in this group. Of those, 41 fell within the range 12-40 years. The results of comparison of these data with Hammar (1926) are shown in Table 1. It

TABLE 1

COMPARISON WITH HAMMAR'S DATA: PATIENTS WITH NO THYMIC NEOPLASM

\begin{tabular}{|c|c|c|c|c|}
\hline $\begin{array}{l}\text { Age group } \\
\text { (yr) }\end{array}$ & $\frac{\text { Hammar }}{(\text { No. })(\%)}$ & $\frac{\begin{array}{c}\text { Present } \\
\text { series }\end{array}}{(\text { No. })(\%)}$ & $\begin{array}{c}\text { Student's } \\
\text { t test }\end{array}$ & $P$ \\
\hline $\begin{array}{l}\text { 11-20 } \\
\text { Cortex } \\
\text { Medulla }\end{array}$ & $\begin{array}{ll}45 & \\
& 38 \cdot 5 \\
& 26 \cdot 6\end{array}$ & $\begin{array}{ll}14 & \\
& 24 \cdot 7 \\
& 32 \cdot 7\end{array}$ & $\begin{array}{l}3 \cdot 799 \\
2 \cdot 880\end{array}$ & $\begin{array}{l}0.0002 \\
0.003\end{array}$ \\
\hline $\begin{array}{l}21-30 \\
\text { Cortex } \\
\text { Medulla }\end{array}$ & $\begin{array}{ll}40 & \\
& 21 \cdot 6 \\
& 20 \cdot 9\end{array}$ & $\begin{array}{rr}14 & \\
& 19 \cdot 8 \\
24 \cdot 7\end{array}$ & $\begin{array}{l}0 \cdot 266 \\
1 \cdot 488\end{array}$ & $\begin{array}{l}0.356 \\
0.072\end{array}$ \\
\hline $\begin{array}{l}31-40 \\
\text { Cortex } \\
\text { Medulla }\end{array}$ & $\begin{array}{rr}21 & \\
& 11 \cdot 7 \\
& 11 \cdot 8\end{array}$ & $13 \begin{array}{rr}12 \cdot 4 \\
\\
\\
& 20 \cdot 5\end{array}$ & $\begin{array}{l}0.262 \\
2 \cdot 943\end{array}$ & $\begin{array}{l}0.398 \\
0.003\end{array}$ \\
\hline
\end{tabular}

will be noted that the percentage of thymus occupied by medulla is significantly increased in the second and fourth decades and that the percentage cortex is considerably decreased in the second decade.

Adult myasthenia gravis associated with thymic tumour Only six subjects with thymic tumour had detectable residual or non-neoplastic thymic tissue. Of these, four subjects were between 40 and 60 years (the others were 32 years and 65 
TABLE 2

COMPARISON WITH HAMMAR'S DATA: RESIDUAL THYMUS IN PATIENTS WITH THYMIC TUMOURS

\begin{tabular}{|c|c|c|c|c|}
\hline $\begin{array}{l}\text { Age group } \\
(y r)\end{array}$ & $\underset{(\%)}{\operatorname{Hammar}}$ & $\begin{array}{c}\begin{array}{c}\text { Present } \\
\text { series }\end{array} \\
(\text { No. })(\%)\end{array}$ & $\begin{array}{c}\text { Student's } \\
\mathrm{t} \text { test }\end{array}$ & $P$ \\
\hline $40-60$ & & $4^{*}$ & & \\
\hline $\begin{array}{l}\text { Cortex } \\
\text { Medulla }\end{array}$ & $\begin{array}{l}7 \cdot 8 \\
6.7\end{array}$ & $\begin{array}{r}7.0 \\
10.5\end{array}$ & $\begin{array}{l}0 \cdot 204 \\
0 \cdot 107\end{array}$ & $\begin{array}{l}0.42 \\
0.15\end{array}$ \\
\hline
\end{tabular}

* Two subjects aged 32 years and 65 years are omitted.

years of age). Comparison with Hammar's data (Table 2) shows increase in the proportion of medulla and decrease in the proportion of cortex but these are not statistically significant.

DENSITY OF GERMINAL CENTRES AND ROUNDED LYMPHOID CLUSTERS Response to thymectomy No relationship was detectable between response to operation and density of reactive lymphoid

TABLE 3

RESPONSE TO THYMECTOMY

\begin{tabular}{|c|c|c|c|}
\hline & $r$ & $t$ & $P$ \\
\hline $\begin{array}{l}\text { Response/GC per } \mathrm{cm}^{2} \text { cortex } \\
\text { Response/GC }+\mathrm{RLC} \text { per } \mathrm{cm}^{2} \text { cortex } \\
\text { Response/GC per } \mathrm{cm}^{2} \text { medulla } \\
\text { Response/GC }+ \text { RLC per } \mathrm{cm}^{2} \text { medulla }\end{array}$ & $\begin{array}{l}-0 \cdot 147 \\
-0 \cdot 149 \\
-0 \cdot 129 \\
-0.071\end{array}$ & $\begin{array}{l}-0.983 \\
-1.001 \\
-0.861 \\
-0.471\end{array}$ & $\begin{array}{l}0 \cdot 160 \\
0 \cdot 197 \\
0 \cdot 320 \\
0 \cdot 055\end{array}$ \\
\hline $\begin{array}{l}\text { Non-neoplastic cases } \\
\text { Response/GC per } \mathrm{cm}^{2} \text { cortex } \\
\text { Response/GC }+ \text { RLC per } \mathrm{cm}^{2} \text { cortex } \\
\text { Response/GC per } \mathrm{cm}^{2} \text { medulla } \\
\text { Response/GC }+ \text { RLC per } \mathrm{cm}^{2} \text { medulla }\end{array}$ & $\begin{array}{l}-0 \cdot 186 \\
-0 \cdot 190 \\
-0 \cdot 180 \\
-0 \cdot 137\end{array}$ & $\begin{array}{l}-1 \cdot 640 \\
-1 \cdot 190 \\
-1 \cdot 125 \\
-0 \cdot 854\end{array}$ & $\begin{array}{l}0 \cdot 055 \\
0 \cdot 121 \\
0 \cdot 134 \\
0 \cdot 199\end{array}$ \\
\hline
\end{tabular}

clusters - that is, germinal centres and RLC expressed as ratios of medulla or cortex (Table 3). Exclusion of the tumour group did not affect this.

Age at operation No correlation was found between age and numbers of reactive lymphoid structures (Table 4). Exclusion of subjects with thymomata did not affect the result.

Duration of symptoms The duration of symptoms before operation bore no relationship to the density of germinal centres and RLC (Table 5).
TABLE 4

RESPONSE TO THYMECTOMY

\begin{tabular}{|c|c|c|c|}
\hline & $r$ & $t$ & $P$ \\
\hline $\begin{array}{l}\text { All cases } \\
\text { Age/GC per } \mathrm{cm}^{2} \text { cortex } \\
\text { Age } / \mathrm{GC}+\mathrm{RLC} \text { per } \mathrm{cm}^{2} \text { cortex } \\
\text { Age/GC per } \mathrm{cm}^{2} \text { medulla } \\
\text { Age/GC+ } / \mathrm{RLC} \text { per } \mathrm{cm}^{2} \text { medulla }\end{array}$ & $\begin{array}{l}0.142 \\
0.143 \\
0.083 \\
0.027\end{array}$ & $\begin{array}{l}0.955 \\
0.957 \\
0.553 \\
0.122\end{array}$ & $\begin{array}{l}0.173 \\
0.172 \\
0.292 \\
0.452\end{array}$ \\
\hline $\begin{array}{l}\text { Non-neoplastic cases } \\
\text { Age/GC per } \mathrm{cm}^{2} \text { cortex } \\
\text { Age/GC + RLC per } \mathrm{cm}^{2} \text { cortex } \\
\text { Age/GC per } \mathrm{cm}^{2} \text { medulla } \\
\text { Age/GC + RLC per } \mathrm{cm}^{2} \text { medulla }\end{array}$ & $\begin{array}{r}0.219 \\
0.221 \\
-0.060 \\
-0.020\end{array}$ & $\begin{array}{r}1.386 \\
1.399 \\
-0.408 \\
-0.122\end{array}$ & $\begin{array}{l}0.087 \\
0.085 \\
0.343 \\
0.452\end{array}$ \\
\hline
\end{tabular}

TABLE 5

DURATION OF SYMPTOMS

\begin{tabular}{|c|c|c|c|}
\hline & $r$ & $t$ & $P$ \\
\hline $\begin{array}{l}\text { All cases } \\
\text { Duration/GC per } \mathrm{cm}^{2} \text { cortex } \\
\text { Duration/GC+RLC per } \mathrm{cm}^{2} \text { cortex } \\
\text { Duration/GC per } \mathrm{cm}^{2} \text { medulla } \\
\text { Duration/GC+LVC } \mathrm{cm}^{2} \text { medulla }\end{array}$ & $\begin{array}{l}-0.013 \\
-0.016 \\
-0.198 \\
-0.231\end{array}$ & $\begin{array}{l}-0.086 \\
-0 \cdot 109 \\
-1 \cdot 342 \\
-1 \cdot 574\end{array}$ & $\begin{array}{l}0.466 \\
0.499 \\
0.093 \\
0.061\end{array}$ \\
\hline $\begin{array}{l}\text { Non-neoplastic cases } \\
\text { Duration/GC per } \mathrm{cm}^{2} \text { cortex } \\
\text { Duration/GC+RLC per } \mathrm{cm}^{2} \text { cortex } \\
\text { Duration/GC per } \mathrm{cm}^{2} \text { medulla } \\
\text { Duration/GC }+R L C \text { per } \mathrm{cm}^{2} \text { medulla }\end{array}$ & $\begin{array}{r}0.016 \\
0.000 \\
-0.173 \\
-0.181\end{array}$ & $\begin{array}{r}0.156 \\
0.002 \\
-1.085 \\
-1 \cdot 132\end{array}$ & $\begin{array}{l}0.438 \\
0.499 \\
0 \cdot 142 \\
0.132\end{array}$ \\
\hline
\end{tabular}

CORRELATION BETWEEN REACTIVE LYMPHOID STRUCTURE SIZE AND RESPONSE TO THYMECTOMY No correlation was detectable.

TABLE 6

RESPONSE TO THYMECTOMY

\begin{tabular}{lcc}
\hline & Favourable & Unfavourable \\
\hline Average diameter of GC and RLC & $0.400 \pm 0.096$ & $0.385 \pm 0.012$ \\
Student's $t$ test & \multicolumn{2}{c}{0.866} \\
Probability & 0.193 \\
& \\
\hline
\end{tabular}

\section{DISCUSSION}

COMPARISON WITH HAMMAR'S DATA There is a relative decrease in the percentage area of thymus occupied by cortex and a relative increase in the amount of medulla compared to Hammar's data for subjects who died suddenly. This is highly significant statistically for the alterations in 
medulla in the 11-20 year and 31-40 year groups and for the altered cortical values in the 11-20 year group.

Hammar's data, obtained with meticulous attention to detail, represent the best available data on the values of normal thymic tissue. Two explanations are possible for the apparent increase in the medulla in myasthenia gravis: (1) this is genuine medullary hyperplasia; (2) the changes are due to stress.

It would be possible to resolve this difficulty if the precise weight of each thymus had been determined. It would then have been possible to calculate the mass of each tissue component. Unfortunately, it was not possible to determine the weight of each gland with sufficient precision in many cases. However, the alterations in the relative proportions of cortex and medulla are similar to those detected in individuals who are stressed by illness for several days before death (Hammar, 1929). It is therefore reasonable to conclude that, while the data may indicate a genuine increase in medullary tissue - that is, true medullary hyperplasia-it is equally likely that the changes are due to stress. Moreover, the data of Castleman and Norris (1949) show that it is more common for myasthenic thymus glands to weigh less than average, compared with normal subjects of the same age. The term 'thymic hyperplasia' is therefore misleading and should be avoided.

CORRELATION OF HISTOLOGICAL FEATURES WITH RESPONSE TO SURGERY Previous studies into a possible relationship between the histological appearances of thymus glands removed surgically for myasthenia gravis and the postoperative response have fallen into three groups: (1) no relationship (Castleman and Norris, 1949; Seybold et al., 1971; Reinglass and Brickel, 1973); (2) favourable response correlates with presence of numerous germinal centres (Mackay et al., 1968); (3) favourable response more likely in thymus glands with few germinal centres (Alpert et al., 1971).

No previous authors have used quantitative methods. The only previous studies to use semiquantitative methods were those of Alpert et al. and Reinglass and Brickel. The study of Mackayet al. (1968) used subjective assessment of the histological changes. The period of follow-up was short-a maximum of 30 months. In addition, the group studied by Mackay was small and contained an unusually high proportion of subjects with thymic tumours. It is therefore reasonable to regard these results as being anomalous because of the small number of cases studied.

The study of Alpert et al. (1971) also included a relatively high proportion of patients with thymic tumours (27 out of 79 cases) but the period of follow-up was much longer and the histological assessment was made in a semiquantitative manner. Alpert and his associates concluded that the patients with the least reactive thymus glands tend to experience more rapid benefit from thymectomy.

Reinglass and Brickel (1973) studied 12 patients, most of whom were young females; none of their subjects had thymic tumours. They used semiquantitative methods and were unable to detect any correlation between the result of thymectomy and the histological appearances of the thymus. The seven patients who benefited from thymectomy did so within one year of surgery.

The present study shows a tendency for better results to be obtained in subjects with relatively non-reactive thymus glands, but the results are not statistically significant. They are therefore not in disagreement with the conclusions of Castleman and Norris (1949), Seybold et al. (1971), and Reinglass and Brickel (1973) who failed to find any connection between the postoperative response and the histological appearances of the resected thymus glands.

A study of the data presented by Alpert and his associates also shows a tendency for patients with relatively non-reactive thymus glands to respond favourably. However, the difference in incidence of thymic germinal centres between those who respond favourably and those who do not experience benefit from thymectomy is not statistically significant. Additionally, statistical analysis of the data given in Alpert et al.'s Fig. 3 shows that there is no statistical difference in the incidence of germinal centres between the group of patients who developed remission within one year and those who developed a clinical remission after two years. Although both the present group and that of Alpert et al. show a tendency to obtain better results in subjects with relatively non-reactive thymus glands, neither 
groups' data achieve statistical significance. Unfortunately, because of differences in the quantitation methods used, it is not possible to pool the results in an attempt to achieve statistical significance.

The hypothesis advanced by Alpert et al. (1971) that the myasthenic thymus produces lymphocytes which in turn induce neuromuscular damage is an attractive one. In view of the wellknown long life span of thymic derived lymphocytes it would be reasonable to assume that the more active the thymus is in producing lymphocytes which can induce neuromuscular damage, the longer it would take for a patient to undergo remission.

An alternative hypothesis, advanced by Gideon Goldstein (Goldstein, 1966) that the thymus in myasthenia gravis is damaged by an autoimmune reaction 'thymitis' and releases excessive amounts of a postulated neuromuscular transmission inhibiting hormone 'thymin' has several flaws. Firstly, the presence of lymphoid follicles in human thymus which Mackay et al. (1968) term 'thymitis' is not specific for myasthenia gravis. Lymphoid follicles are readily detectable in many young subjects who die suddenly (Middleton, 1967), or who have operations to correct congenital heart disease (Henry, 1968; Vetters and Barclay, 1973). Further, lymphoid follicles are seen frequently in other diseases now believed to have an autoimmune basis-indeed, Sloan (1943) observed lymphoid follicle formation in subjects with Addison's disease, acromegaly, and thyrotoxicosis. It would therefore be necessary to postulate that only one disease with thymic germinal centre formation causes excessive release of 'thymin' while others, histologically identical, do not. Secondly, if 'thymin' does exist and is a hormone, its site of production in the thymus has not been elicited. It is true that ultrastructural evidence of hormone production by the thymus (in Hassall's corpuscles) has been produced by Vetters and Macadam (1973), but we do not believe this substance is 'thymin' but 'thymosin', a hormone isolated by Allan Goldstein (Goldstein et al, 1972) and detected in peripheral blood by Bach (1973). This conclusion is supported by the fact that, in some patients with a congenital deficiency of $T$ cell function, the Hassall's corpuscles are absent. Further, to date no observations have been made of specific abnormalities in the structure or form $\frac{C}{0}$ of Hassall's corpuscles in myasthenia gravis.

Careful histological assessment of myasthenic thymus glands has failed to detect a statistically significant relationship between germinal centre formation and the response to thymectomy. It remains to be determined whether any histological features will correlate better.

\section{REFERENCES}

Alpert, L. I., Papatestas, A., Kark, A., Osserman, R. S and Osserman, K. (1971). A histologic reappraisal of the thymus in myasthenia gravis. Archives of Pathology, 91, 55-61.

Bach, J.-F., Dardenne, M., Papiernik, M., Barois, A., Levasseur, P., and Le Brigand, H. (1972). Evidence for a serum-factor secreted by the human thymus. Lancet, 2 , 1056-1058.

Barton, F. E., and Branch, C. F. (1937). Myasthenia gravis: $\omega$ report of a case with necropsy. Journal of the American Medical Association, 109, 2044-2048.

Castleman, B., and Norris, E. H. (1949). The pathology the thymus in myasthenia gravis. Medicine (Balt.), 280 27-58.

Goldstein, A. L., Guha, A., Zatz, M. M., Hardy, M. A., an£ White, A. (1972). Purification and biological activity thymosin, a hormone of the thymus gland. Proceedings of the National Academy of Science of the United States America, 69, 1800-1803.

Goldstein, G. (1966). Thymitis and myasthenia gravi Lancet, 2, 1164-1167.

Goldstein, G., and Mackay, I. R. (1967). The thymus in systemic lupus erythematosus; a quantitative histopathological analysis and comparison with stress involution. British Medical Journal, 2, 475-478.

Hammar, J. A. (1926). Die Menschenthymus in Gesundheit und Krankheit. 1. Das normale Organ. Akademische Verlagsgesellschaft: Leipzig.

Hammar, J. A. (1929). Die Menschenthymus in Gesundheit und Krankheit. 2. Das Organ unter anormalen Körperverhältnissen. Akademische Verlagsgesellschaft: Leipzig.

Henry, K. (1968). The thymus in rheumatic heart disease. Clinical and Experimental Immunology, 3, 509-523.

Keynes, G. (1946). The surgery of the thymus gland. British Journal of Surgery, 33, 201-214.

Keynes, G. (1949). The results of thymectomy in myasthenia gravis. British Medical Journal, 2, 611-616.

Mackay, I. R., Whittingham, S., Goldstein, G., Currie, T. T., and Hare, W. S. C. (1968). Myasthenia gravis: clinical, serological and histological studies in relation to thymectomy. Australasian Annals of Medicine, 17, 1-11.

Middleton, G. (1967). The incidence of follicular structures in the human thymus at autopsy. Australian Journal of Experimental Biology and Medical Science, 45, 189-199.

Miller, H. G. (1940). Myasthenia gravis and the thymus gland. Archives of Pathology, 29, 212-219.

Reinglass, J. L., and Brickel, A. C. J. (1973). The prognostic significance of thymic germinal center proliferation in myasthenia gravis. Neurology (Minneap.), 23, 69-72. 
Seybold, M. E., Howard, F. M., Jr, Duane, D. D., Payne, W. S., and Harrison, E. G., Jr. (1971). Thymectomy in juvenile myasthenia gravis. Archives of Neurology, 25, 385-392.

Sloan, H. E., Jr (1943). The thymus in myasthenia gravis. Surgery, 13, 154-174.

Sousa, M. de, and Fachet, J. (1972). The cellular basis of the mechanism of action of cortisone acetate on contact sensitivity to oxazolone in the mouse. Clinical and Experimental Immunology, 10, 673-684.

Vetters, J. M., and Barclay, R. S. (1973). The incidence of germinal centres in thymus glands of patients with congenital heart disease. Journal of Clinical Pathology, 26, 583-591.

Vetters, J. M., and Macadam, R. F. (1973). Fine structural evidence for hormone secretion by the human thymus. Journal of Clinical Pathology, 26, 194-197. 